\title{
Efficacy of Trichoderma spp. and fungicides against Lasiodiplodia theobromae
}

\author{
Mousumi Bhadra*, Abul Khair, Md. Anawar Hossain and Md.Maniruzzaman Sikder
}

Department of Botany, Jahangirnagar University, Savar, Dhaka-1342, Bangladesh

\begin{abstract}
Experiments were carried out to find out the bio-efficacy of four Trichoderma species, viz. Trichoderma harzianum, T.koningii, T.viride (green strain), T.viride (yellow strain) against canker pathogen Lasiodiplodia theobromae. Bioassay of antagonist against test pathogens conducted by dual culture techniques at different temperatures; volatile, non volatile and naturally untreated metabolites of isolates were examined. T. koningii and T.viride (yellow strain) exhibited maximum inhibition in controlling the pathogens. Fungicides, viz. Bavistin and Dithane M-45 used where Bavistin found little effective but Dithane M-45 showed no effects on pathogen. Trichoderma viride showed better performance to control Lasiodiplodia theobromae than commercial fungicides used during present investigation.
\end{abstract}

Keywords: Trichoderma spp; Biological control; Lasiodiplodia theobromae

\section{Introduction}

Species of the Botryosphaeriaceae have a cosmopolitan distribution which occurs on a wide range of monocotyledonous, dicotyledonous and gymnospermous hosts, as well as on lichen thalli. Lasiodiplodia theobromae (Syn. Botryodiplodia theobromae) belongs to Botryosphaeriaceae, are associated with different symptoms such as shoot blights, stem cankers, fruit rots, die-back, gummosis (Ciesla et al., 1996), canker and die-back, followed by kino exudation, and in severe cases tree death (Shearer et al. 1987; Smith et al. 1994; Old \& Davison 2000; Roux et al. 2001). Ciesla et al., (1996) reported that species of the Botryosphaeriaceae are generally regarded as weak pathogens that invade stressed or wounded plants after drought, hail, wind, frost or insect damage and was also cited that the Botryosphaeriaceae occur in asymptomatic tissue as latent pathogens in trees such as Eucalyptus, Pinus and Syzigium (Pavlic et al., 2004). Hence, present investigation was carried out to investigate the efficacy of biological agents; Trichoderma spp. and fungicides against L.theobromae causing disease in plants.

\section{Material and Methods}

Four species of Trichoderma namely, Trichoderma harzianum, T.koningii, T.viride (green strain), T.viride (yellow strain) were isolated from spent (infected) mushroom spawn packets of Pleurotus ostreatus (Jacquin ex fr.) Kummer, during December'2010 to February'2011. Lasiodiplodia theobromae was also isolated from wood samples (saw dust) which used as raw materials for spawn packets preparation to grow commercial mushroom at National Mushroom Development and Extension Centre, Savar, Dhaka. After Surface sterilized samples were inoculated on PDA plates and incubated at three different temperatures viz. $20 \pm 2^{\circ} \mathrm{C}, 28 \pm 2^{\circ} \mathrm{C}, 35^{\circ} \mathrm{C}$. Radial growth of mycelium were measured. Mycelium of the pathogens was spread over the whole plate after 3 days and sub-cultured on PDA slants and incubated for further growth. Cultural and microscopic characteristics were observed under microscope.

\section{In vitro assay of antagonists by Dual culture technique}

Trichoderma isolates were evaluated against Lasiodiplodia theobromae by dual culture technique as described by Kunz (2007). A $5 \mathrm{~mm}$ diameter mycelial disc from the margin of the 7 days-old culture of Trichoderma isolates and the Lasiodiplodia theobromae was placed on the PDA media at opposite of the plate at equal distance from the periphery. In control plates, (without Trichoderma), a sterile agar disc was placed at centre of the plates. Inoculated plates were incubated at $28 \pm 2^{\circ} \mathrm{C}, 32 \pm 2^{\circ} \mathrm{C}$, and $35^{\circ} \mathrm{C}$ until the end of the incubation period of 7 days. Inhibition percent was calculated (Kunz, 2007) by the following formulae:

$$
\begin{aligned}
& \% \text { inhibition }=\mathrm{C}-\mathrm{T} / \mathrm{C} \times 100 \\
& \text { Where, } \\
& \mathrm{C}=\text { Radial growth of control plates. }
\end{aligned}
$$


$\mathrm{T}=$ Radial growth of treated plates.

Volatile metabolites from antagonists on Lasiodiplodia theobromae

The effect of released volatile metabolites of Trichoderma isolates on the mycelial growth of the pathogen was evaluated as methods described by Dennis and Webster (1971). Test pathogens were inoculated at the centre on PDA plates with $5 \mathrm{~mm}$ diameter mycelial growth and Trichoderma inoculated plates were inverted on the top of the test pathogens plates and held together by adhesive tape. Radial growths of the pathogens were recorded at 24 hours interval at room temperature $\left(28 \pm 2^{\circ} \mathrm{C}\right)$.

Effects of non volatile metabolites on Lasiodiplodia theobromae

The method was followed as described by Kaur et al. (2006). Three mycelial agar blocks, each having $5 \mathrm{~mm}$ diameter of four individual fungal antagonists, were cut off from the advanced margins of 5 day old culture and inoculated into a $500 \mathrm{ml}$ conical flask containing $250 \mathrm{ml}$ potato dextrose broth medium. The inoculated flasks were allowed for 15 days incubation period at $28 \pm 2^{\circ} \mathrm{C}$. After incubation, the culture broth of each antagonist was filtered through a double ring filter paper $(11 \mathrm{~cm})$ and finally
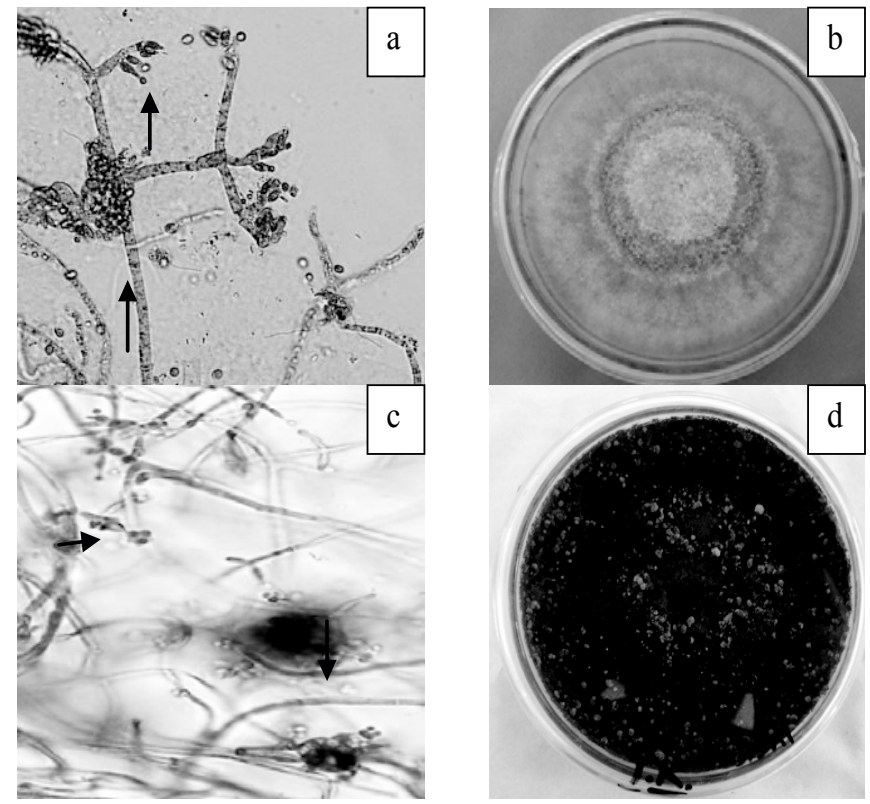

through a millipore filter paper under suction pump to obtain cell and bacteria free extracts under aseptic conditions. All plates were incubated at room temperature $28 \pm 2^{\circ} \mathrm{C}$ and percent inhibition in mycelia growth was calculated. The effects of natural untreated metabolites by dipping culture disc method was followed as described by Ashrafuzzaman and Aminur (1992).

\section{In vitro assay of fungicides}

The effect of fungicides, namely Bavistin and Diathane-M 45 were used to examine the effectiveness against $L$. theobromae on PDA medium using $30 \mathrm{ppm}, 50 \mathrm{ppm}, 70$ $\mathrm{ppm}$ concentration of each fungicides. Three replicated PDA plates were used for each dose of fungicides. PDA plate received no fungicide was served as control. The inoculated plates were incubated at $28 \pm 2^{\circ} \mathrm{C}$ and percent of inhibition was calculated.

\section{Results and Discussion}

T. harzianum was characterized based on morphology such as colonies, hyphae, conidiophores, phialides and conidia according to Choi In-Young et al. (2003). Other strains of Trichoderma in the present study were characterized as described by Bernet (1960); Choi In-Young et al. (2010).
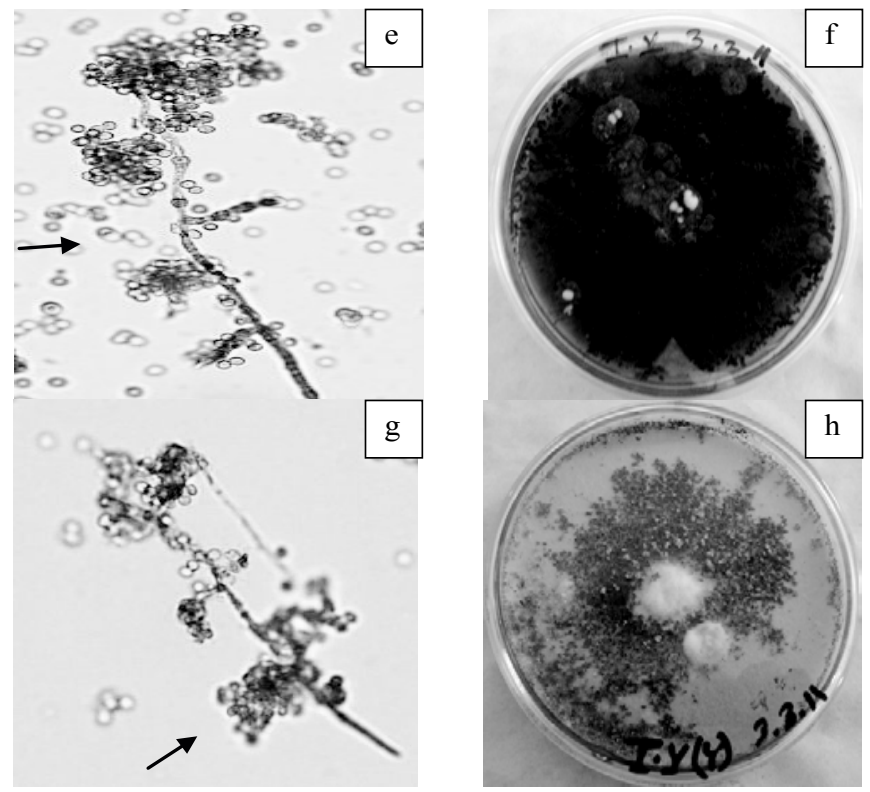

Plate. Photographs showing cultural and microscopic features of Trichoderma spp. (magnification 40X)

a \& b. Microscopic features and colony of Trichoderma harzianum showing phialides, conidia

c \& d. Microscopic features and colony of Trichoderma koningii showing phialides, conidia,coiling

e \& f. Microscopic features and colony of Trichoderma viride (green strain) showing spores

$\mathbf{g} \boldsymbol{\&}$ h. Microscopic features and colony of Trichoderma viride (yellow strain) showing spores 
The cultural and microscopic observation of the mycelia, spores of $L$. theobromae was confirmed, as described by Kunz (2007). Off-white colored immature colony appeared which turned into black color within 2-3 weeks. Colonies were luxuriant with regular fast growth. Black septate mycelium with colourless and unicellular spores was found at young stage. Upon maturity, spores became brown colored, distichously and thick walled. Spores were elliptical and larger in sized. The cultural and microscopic observation of the mycelia, spores of $L$. theobromae was confirmed, as

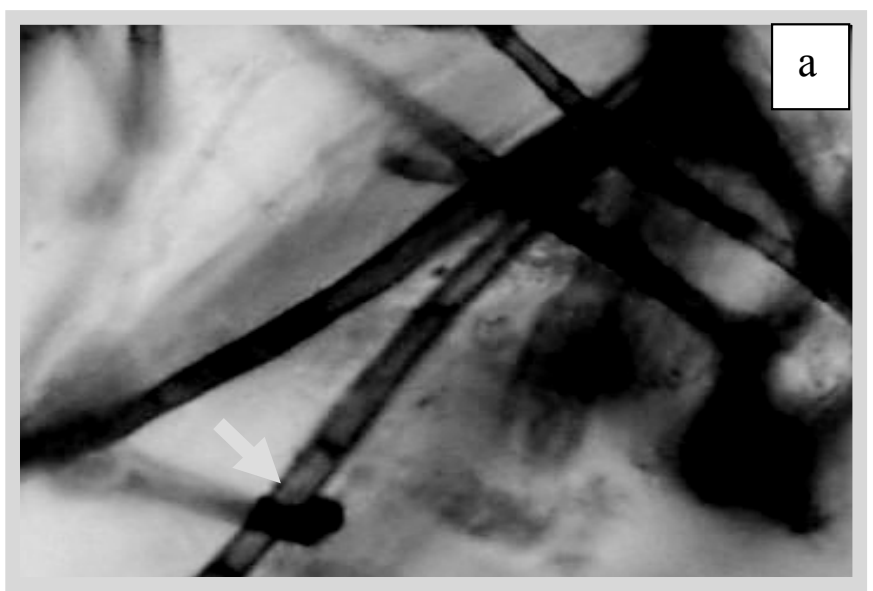

Fig. (a) Septed mycelium of L.theobromae

described by Kunz (2007).

Findings of the dual culture tests demonstrated that all the Trichoderma isolates tested showed inhibitory effects against Lasiodiplodia theobromae ranged from $60-75 \%$ at $28 \pm 2{ }^{\circ} \mathrm{C}$ temperature whereas the maximum inhibition (80\%) was exhibited by both T.koningii and T.viride (green strain) at $32 \pm 2{ }^{\circ} \mathrm{C}$ and $35^{\circ} \mathrm{C}$ temperature (Table I). In case of volatile metabolites, T.viride (green strain) showed maximum inhibition $(33.3 \%)$ whereas non volatile and naturally untreated metabolites of fungal cultures did not perform any significant reduction of mycelial growth of $L$. theobromae (Table 1). The mode of action of Trichoderma spp. showed mycoparasitism and competition for space and nutrients in dual culture which are in agreement with Kotze (2008). The antagonistic potentiality of

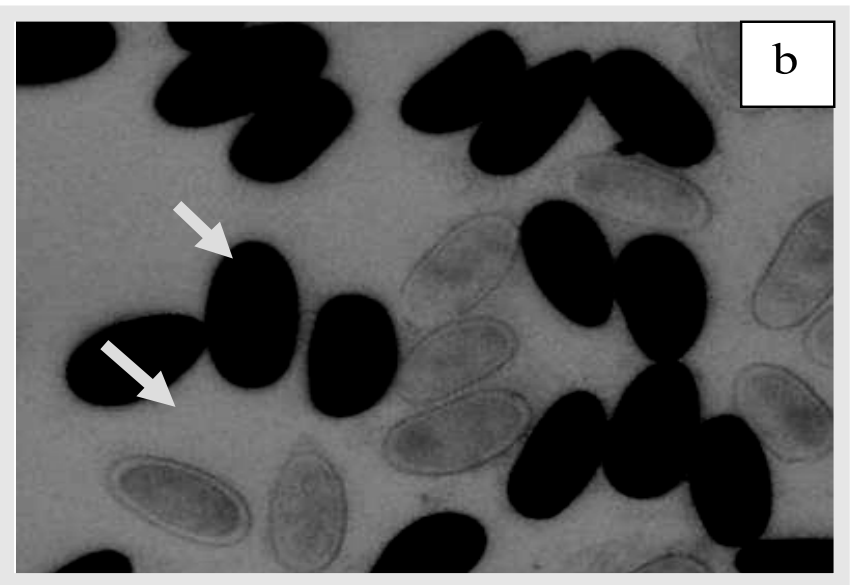

Fig. (b) Bi-celled mature spore and single celled immature spore of L.theobromae

Trichoderma spp. against Lasiodiplodia theobromae was also reported by earlier workers (Mortuza and Ilag, 1999, Yadav \& Majumdar, 2005, Kunz, 2007). Mortuza and Ilag
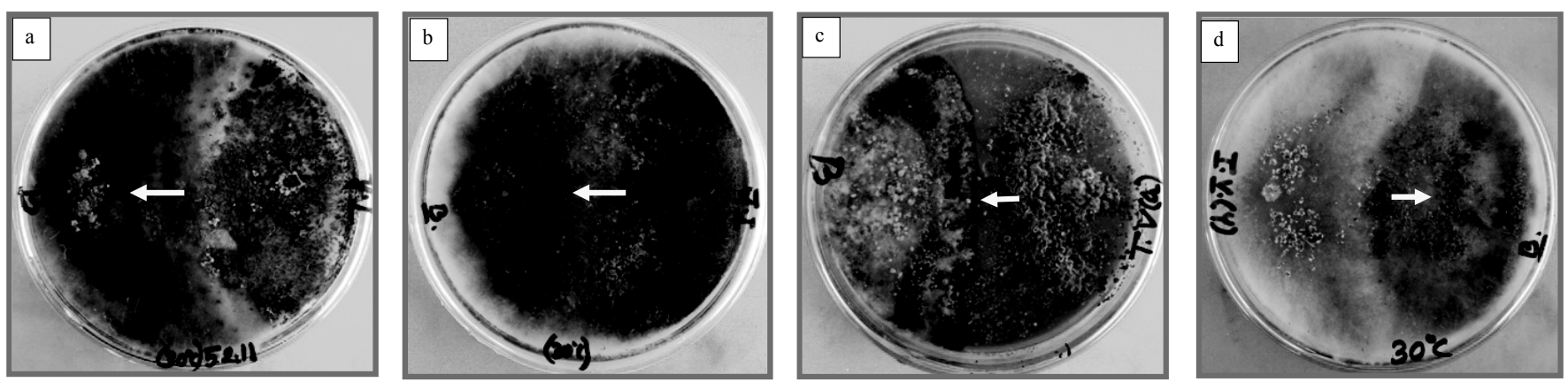

Plate. Photographs showing growth and antagonistic activity of four Trichoderma spp. against Lasiodiplodia theobromae on PDA medium

a. Overgrowth of T.harzianum to Lasiodiplodia theobromae

b. Overgrowth of T.koningii to Lasiodiplodia theobromae

c. Inhibittion zone between colonies of Lasiodiplodia theobromae and T.viride (yellow strain)

d. Overgrowth of T.viride (yellow strain) to Lasiodiplodia theobromae 
(1999) cited that T.harzianum exhibited the greatest inhibition in dual culture, whereas Yadav \& Majumdar (2005) reported that $T$. viride was more effective than $T$. harzianum.

Volatile metabolites from Trichoderma viride only inhibit (33.3\%) the growth of fungi, Lasiodiplodia theobromae. Present findings have partially conformity with the results of Kotze (2008) who reported $23.6 \%$ inhibition by $T$. atroviride. During present study, non volatile metabolites had no effects on Lasiodiplodia theobromae which contradict to results cited by John et al. (2004).

During present investigations fungicide Bavistin found effective to control Lasiodiplodia theobromae at $70 \mathrm{ppm}$ than others used, whereas Dithane M-45 showed no significant effect at any concentration (Table 2). These findings are contradictory with Yadav \& Majumdar

Table I. In vitro percent of inhibition of Lasiodiplodia theobromae by four Trichoderma spp. at different temperatures (7 days after incubation)

\begin{tabular}{|c|c|c|c|c|c|c|}
\hline \multirow{3}{*}{ Antagonists } & \multicolumn{6}{|c|}{$\%$ of inhibition of Lasiodiplodia theobromae } \\
\hline & \multicolumn{3}{|c|}{ Dual culture } & \multirow{2}{*}{$\begin{array}{r}\text { Volatile } \\
28 \pm 2{ }^{\circ} \mathrm{C}\end{array}$} & \multirow{2}{*}{$\begin{array}{c}\text { Non volatile } \\
28 \pm 2{ }^{\circ} \mathrm{C}\end{array}$} & \multirow{2}{*}{$\begin{array}{c}\text { Naturally untreated } \\
28 \pm 2{ }^{\circ} \mathrm{C}\end{array}$} \\
\hline & $28 \pm 2{ }^{\circ} \mathbf{C}$ & $32 \pm 2{ }^{\circ} \mathrm{C}$ & $35^{\circ} \mathrm{C}$ & & & \\
\hline T. harzianum & 60 & 75 & $\mathrm{NE}$ & $\mathrm{NE}$ & $\mathrm{NE}$ & $\mathrm{NE}$ \\
\hline T. koningii & 75 & 80 & 80 & NE & $\mathrm{NE}$ & $\mathrm{NE}$ \\
\hline T. viride (green strain) & 60 & 75 & $\mathrm{NE}$ & 33.3 & $\mathrm{NE}$ & $\mathrm{NE}$ \\
\hline T. viride (yellow strain) & 70 & 80 & 80 & $\mathrm{NE}$ & $\mathrm{NE}$ & $\mathrm{NE}$ \\
\hline
\end{tabular}

Note:NE $=$ No effect

Table II. Effect of different concentration of Bavistin and Diathane M-45 on mycelia growth of L. theobromae at $28 \pm 2^{\circ} \mathrm{C}$ temperature

\begin{tabular}{ccc}
\hline \multirow{2}{*}{ Concentration of fungicides } & \multicolumn{2}{c}{ \% of growth inhibition of $L$. theobromae } \\
\cline { 2 - 3 } $\mathbf{3 0} \mathbf{~ p p m}$ & Bavistin & Diathane M-45 \\
\hline $\mathbf{5 0} \mathbf{~ p p m}$ & $0.58 \pm 0.58 \mathrm{c}$ & $\mathrm{NE}$ \\
$\mathbf{7 0} \mathbf{~ p p m}$ & $0.06 \pm 0.06 \mathrm{~b}$ & $\mathrm{NE}$ \\
\hline
\end{tabular}

- Data recorded after 7 days of incubation 
(2005).

The aggressiveness of Trichoderma spp. studied varies more or less to previously mentioned workers. This might be due to difference in the characteristics of Trichoderma.

So, to control the pathogen by using Trichoderma isolates is an environment friendly and non hazardous approach over chemical control.

\section{References}

Ashrafuzzaman, M.H. and Aminur, R. K. 1992. Antifungal activity in vitro of some plant extract on Rhizoctonia solani. Bangladesh J.Sci.Res. 10(2): 243-244.

Bernet, H.L. 1960. Illustrated Genera of Imperfect Fungi. Second Edition. Burgees Pub. Co. Minneapoils, U.S.A.

Choi In-Young., Choi, J.-N., Praveen, K. S. and Lee. W. H. 2003. Molecular and Morphological Characterization of Green Mold, Trichoderma spp. isolated from Oyster Mushrooms. The Korean Society of Mycology. 31(2): 74-80.

Choi In-Young., Choi, J.-N., Praveen, K. S. and Lee. W. H. 2010. Isolation and Identification of Mushroom Pathogens from Agrocybe aegerita. The Korean Society of Mycology. 38(4): 310-315.

Ciesla, W.M., Diekmann, M. and Putter, C.A.J. 1996. Eucalyptus spp. FAO/IPGRI technical guidelines for the safe movement of germplasm No. 17. Rome, Food and Agriculture Organization of the United Nations \& International Plant Genetic Resources Institute. pp.66.

Dennis, C. J. and J. Webster, 1971. Antagonism properties of species groups of Trichoderma, III. Hyphal interaction. Transactions British Mycological Society. 57: 363-369.

John, J., Joy, M. and Abhilash, E. K. 2004. Inhibitory effects of Tamarind (Tamarindus indica L.) on polypathogenic fungi. Allelopathy J. 14(1): 43-49.
Kaur, M., Sharma, O.P. and Sharma, P.N. 2006. In vitro effect of Trichoderma species on Colletotrichum capsici causing fruit rot of chilli (Capsicum annum L.).Indian Phytopathology. 59(2): 243-245.

Kotze, C. 2008. Biological control of the grapevine trunk disease of pathogens:pruning wound protection. M.S. thesis in agriculture, Stellenbosch University, Private Bag X1, 7602 Matieland (Stellenbosch), South Africa.

Kunz, R. 2007. Control of Post Harvest Disease (Botryodiplodia sp.) of Rambutan and Annona Species by Using a Bio-Control Agent (Trichoderma sp.). Experiments were undertaken by the Industrial Technology Institute (ITI) in cooperation with the International Centre for Underutilised Crops (ICUC).pp. 1-44.

Mortuza, M., Ilag, G. and Lina, L. 1999. Potential for Biocontrol of Lasiodiplodia theobromae (Pat.) Griff. \& Maubl. in Banana Fruits by Trichoderma Species. Biological Control. 15 (3): 235-240.

Old, K.M. and Davison, E.M. 2000. Canker diseases of Eucalypts. In: Diseases and pathogens of Eucalypts (Keane PJ, Kile GA, Podger FD, Brown $\mathrm{BN}$, eds). CSIRO Publishing, Australia.

Pavlic, D., Slippers, B., Coutinho, T.A., Venter, M. and Wingfield, M.J. 2004. Lasiodiplodia gonubiensis sp. nov, a new Botryosphaeria anamorph from native Syzygium cordatum in South Africa. Studies in Mycology 50: 313-322.

Roux, J., Coutinho, T.A., Mujuni, B. D. and Wingfield, M.J. 2001. Diseases of plantation Eucalyptus in Uganda. South African Journal of Science. 97: $16-18$.

Shearer, B.L., Tippett, J.T. and Bartle, J.R. 1987. Botryosphaeria ribis infection associated with death of Eucalyptus radiate in species selection trials. Plant Disease. 71: 140-145. 
Smith, H., Kemp, G.H.J. and Wingfield, M.J. 1994. Canker and die-back of Eucalyptus in South Africa caused by Botryosphaeria dothidea. Plant Pathology. 43: 1031-1034.
Yadav, R.K. and Majumdar. V.L. 2005. Efficacy of Plant Extracts, Biocontrol Agents and fungicides Against Lasiodiplodia theobromae Incited Die -back of Guava (Psidium guajava L.) J.Mycol.Pl.Pathol. 35(2): 352-353.

Received: 11 October 2012; Revised: 31 December 2013; Accepted: 3 June 2014. 